\title{
New method for detecting changes in the surface appearance of human red blood cells
}

\author{
A. J. SAlsBURY AND J. A. CLARKE \\ From the Departments of Haematology and Anatomy, St. Bartholomew's Hospital, London
}

SYNOPSIS A new method for examining the surface of blood cells, using the Stereoscan electron microscope, is described. Some of the cellular appearances revealed by this technique are illustrated. The potentialities and limitations of scanning electron microscopy are discussed.

Until recently methods for examining red blood cells, while ranging in their powers of resolution from optical to ultrastructural levels, have been limited by the two-dimensional concept which is presented, and the use of stereo pictures gives a restricted three-dimensional effect. With the development of the Stereoscan electron microscope an instrument is available for producing a rapid, direct, three-dimensional view of detailed surface structure over a distance of several centimetres with little preparation of tissue.

The current Cambridge Stereoscan electron microscope allows the image of specimen surfaces to be viewed in a different way to the image of ultrathin sections produced for conventional electron microscopy. Using three magnetic electron lenses a demagnified image of the thermionic electron source is produced to give an electron probe size of $50 \AA$. This probe or electron beam moves in turn over each point of the object and the electrons emerging from the specimen are collected and amplified in a photo multiplier. The signal derived controls the brightness of a cathode-ray tube, whose spot moves over a screen in correspondence with the motion of the electron beam over the specimens. Thus any picture on the cathode-ray tube presents a record of the property of the scanned surface or any change in the property. The resolution of the Stereoscan electron microscope with biological specimens is approximately $200 \AA$. As a result a gap is bridged in the available range of investigative equipment between optical and conventional transmission electron microscopes.

At present the Stereoscan electron microscope has been used principally for preliminary studies in biological specimens (Boyde and Stewart, 1963; Oatley, Nixon, and Pease, 1965; Thornton, 1965;
Boyde and Quilliam, 1966) and the altered states of metal surfaces (Thornton, 1965; Oatley et al., 1965).

This communication describes changes in the appearance of human red cell surfaces in various blood disorders, and demonstrates the ability of the Stereoscan electron microscope to show alterations in cell surface structure at a resolution and in a dimension not previously possible. A preliminary note on the surface ultramicroscopy of blood cells has been made separately by the authors (Clarke and Salsbury, 1967).

\section{MATERIALS AND METHODS}

Specimens of venous blood from the antecubital vein were taken into sequestrene in the following instances:-

NORMAL Six subjects (seven samples).

HAEMORRHAGE WITH RETICULOCYTOSIS Five cases (seven samples).

IDIOPATHIC THROMBOCYTOPENIC PURPURA FOLLOWING SPLENECTOMY Three cases (three samples).

IRON-DEFICIENCY ANAEMIA Three cases (three samples). These patients were all severely anaemic, with a hypochromic blood film, a reduced serum iron level, an increased iron-binding capacity, and a reduced marrow iron content.

MEGALOBLASTIC ANAEMIA Four cases (four samples). These patients were all anaemic, macrocytes were present in peripheral blood, the bone marrow was megaloblastic, and the serum vitamin $B_{12}$ or folic acid level was low.

HAEMOGLOBINOPATHY (THALASSAEMIA OR SICKLE CELL ANAEMIA) Ten cases (11 samples). Target cells or sickle cells were present in peripheral blood and the appropriate abnormal haemoglobin had been identified.

HEREDITARY SPHEROCYTOSIS Two cases (two samples). 
Both patients were moderately anaemic; spherocytes were seen in blood films and the red cells showed an increased osmotic fragility. Neither subject had undergone a splenectomy.

aUtormmune haEmolytic anAemia Eight cases (eight samples). These patients showed a severe haemolytic anaemia with a positive direct Coombs test and the presence of warm type antibodies.

HAEMOLYTIC ANAEMIA SECONDARY TO GLANDULAR FEVER One case (two samples).

HAEMOLYTIC ANAEMIA SECONDARY TO INFECTIVE HEPATITIS One case (two samples). Both patients had a moderate haemolytic anaemia with a negative direct Coombs test.

HAEMOLYTIC ANAEMIA SECONDARY TO DRUG SENSITIVITY Four cases (five samples). All cases were secondary to the ingestion of phenacetin in large amounts and showed a moderate haemolytic anaemia with abnormal, 'nibbled' cells in peripheral blood and a negative direct Coombs test.

One patient taking Dapsone with no evidence of haemolysis but with moderate numbers of Heinz bodies in reticulocyte preparations was also included.

HAEMOLYTIC ANAEMIA FROM MECHANICAL CAUSES Two cases (two samples). Both patients possessed StarrEdwards mitral valve prostheses and had a haemolytic anaemia, a negative direct Coombs test, and numerous fragmented cells in blood films.

PAROXYSMAL NOCTURNAL HAEMOGLOBINURIA Four cases (five samples). All patients showed a haemolytic anaemia with a negative direct Coombs test, a positive Ham's test, and the presence of large amounts of haemosiderin in the urine.

A Ham's test was prepared from one sample, specimens of blood for fixation being removed at 2, 5, 10, 20, 30, and 60 minutes of incubation.

SIDEROBLASTIC ANAEMIA Four cases (five samples). These patients possessed a dimorphic peripheral blood film with Pappenheimer bodies in some red cells, a high serum iron level, and a markedly increased marrow iron content with numerous 'ring' sideroblasts. No subjects had undergone a splenectomy.

MISCELlaneous Twenty-two cases (22 samples). These patients comprised six cases of myelomatosis, three of myelofibrosis, one of hereditary elliptocytosis, four of uraemia, five of hepatic cirrhosis, three of acute leukaemia.

HAEMOLYSIS INDUCED IN VITRO There were 13 samples. Of a red cell suspension, $5 \mathrm{ml}$. was incubated with $0.5 \mathrm{ml}$. of $2 \%$ saponin. Samples were taken and fixed at intervals of $2,4,10,20,30$, and 60 seconds after the addition of saponin.

Of a red cell suspension $5 \mathrm{ml}$. was incubated with $1 \mathrm{ml}$. of a solution of reduced streptolysin ' $O$ ' containing 20 I.U. per ml. Samples were taken for fixation at 2, 5, 10, 30, and 60 seconds and at 2 and 5 minutes after the addition of streptolysin.
Red cells were prepared for examination by fixing $\stackrel{2}{\rightleftarrows}$ the sequestrenated whole blood in $0.5 \%$ phosphate 음 buffered glutaraldehyde $(p \mathrm{H} \mathrm{7.4)}$ at room temperature $\ddot{\Rightarrow}$ (Lewis, 1967), washing the cells in distilled water, and making a thin film on a small cover glass which was 0 attached to the aluminium specimen stub. The specimens were covered with a $500 \AA$ thick layer of gold and palladium to render their surfaces conducting. Examination was made in the Cambridge Stereoscan electron microscope and the micrographs recorded with a $20 \mathrm{kV}$ scanning electron beam on an Ilford HP3 film with an exposure time of 20 to $100 \mathrm{sec}$.

\section{RESULTS}

BLOOD FROM NORMAL SUBJECTS The normal red iv blood cell, as might have been expected, had the $A$ appearance of a biconcave disc 7 to $8 \mu$ in diameter. The cells showed a normal degree of anisocytosis, but an average of $2 \%$ were in the region of $6 \mu$ in $\mathrm{O}$ diameter and were less flattened than the majority of cells. The surface of normal cells was uniformly smooth, even at magnifications approaching the limit of resolution of the microscope ( $200 \AA)$.

Occasional red cells were slightly larger than the average, showed a less pronounced central depression and possessed a finely granular surface. Their numbers were increased proportionately in cases of anaemia with a raised reticulocyte count and it seemed reasonable to regard such cells as reticulocytes.

A few red cells from normal subjects showed small, irregular areas with loss of the cell membrane. These areas varied from 1,000 to $3,000 \AA$ in diameter. Small flaps of partly detached cell surface membrane were often present at the margins of these defects. Many similar cells were seen in blood from patients suffering from idiopathic thrombocytopenic purpura following splenectomy (three samples). It is probable that such cells were old red cells exhibiting degenerative changes.

IRON-DEFICIENCY ANAEMIA Red cells in these cases showed more anisocytosis than the cells from normal subjects. Cells were of two types: microcytic cells approximately 5 to $6 \mu$ in diameter, exhibiting a much deeper central depression than the normal red blood cell; red cells 7-8 $\mu$ in diameter which were much flatter than the normal red cell and with a much wider, although relatively shallow, central depression (Fig. 1). The surface of iron-deficiency cells showed no granularity, but was less regular than that of normal red cells. Elliptocytic 'pencil' cells presented a characteristic appearance.

MEGALOBLASTIC ANAEMIA Appearances were unremarkable in these cases. Red cells showed more 


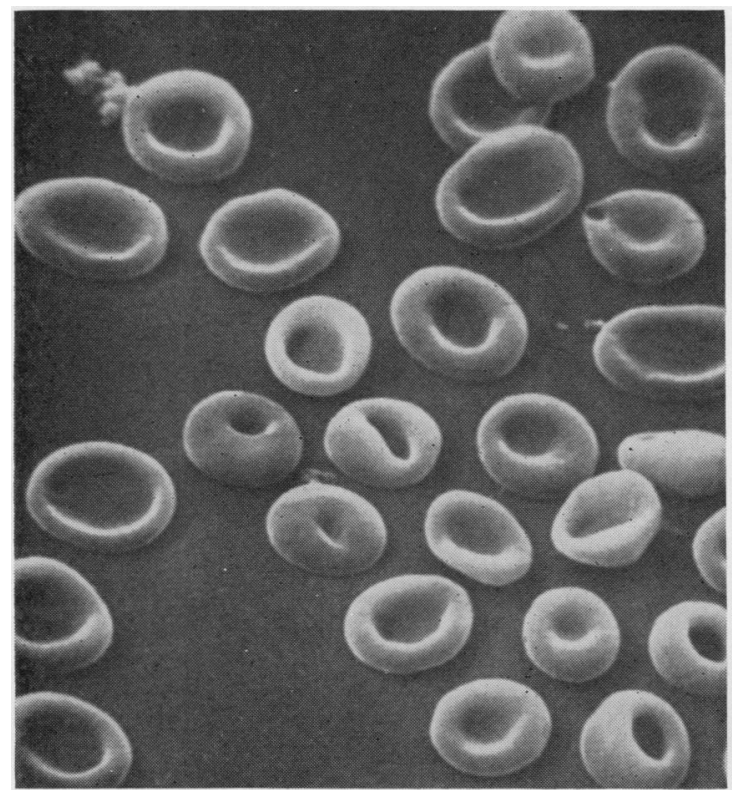

FIG. 1. Iron-deficiency anaemia. $\times 4,200$.

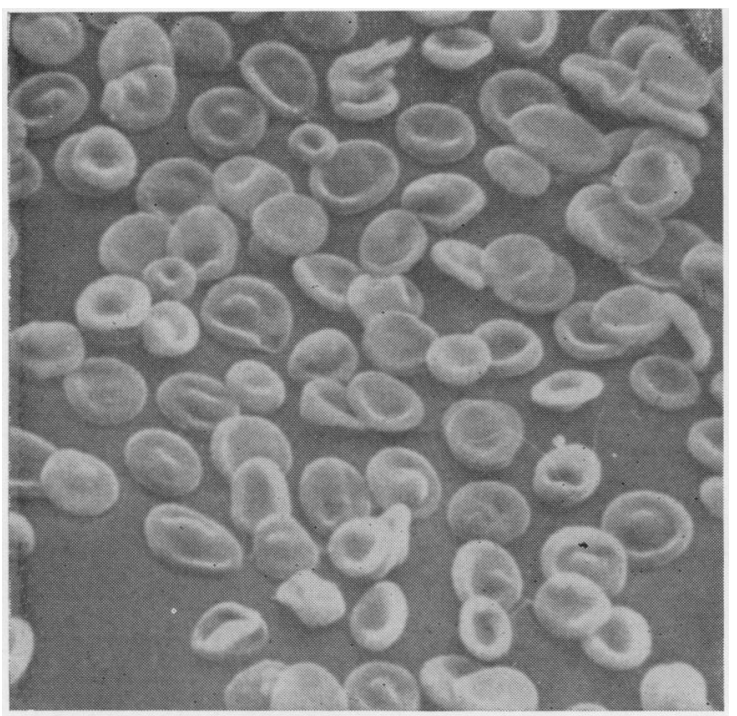

FIG. 2. Thalassaemia major. Note the numerous target cells. $\times 2,000$.

variation in size than normal. Macrocytes possessed a smooth surface and a less pronounced central depression than the normal red cell.

HAEMOGLOBINOPATHIES Target cells in cases of thalassaemia major were readily identified. They possessed either a central hemispherical projection or a more elongated ridge extending across the central depression but not usually in continuity with the outer rim of the cell (Fig. 2). The surface of these cells was relatively smooth. Occasional crenated poikilocytes and elliptocytes were also seen in cases of thalassaemia major.

In preparations of fresh blood from cases of sickle cell anaemia, sickle cells could be seen as slightly elongated cells possessing a narrow central ridge which extended, almost invariably, to the margins of the cell. On incubation of the blood with a reducing agent (sodium metabisulphite), the cells became longer and narrower, the central ridge

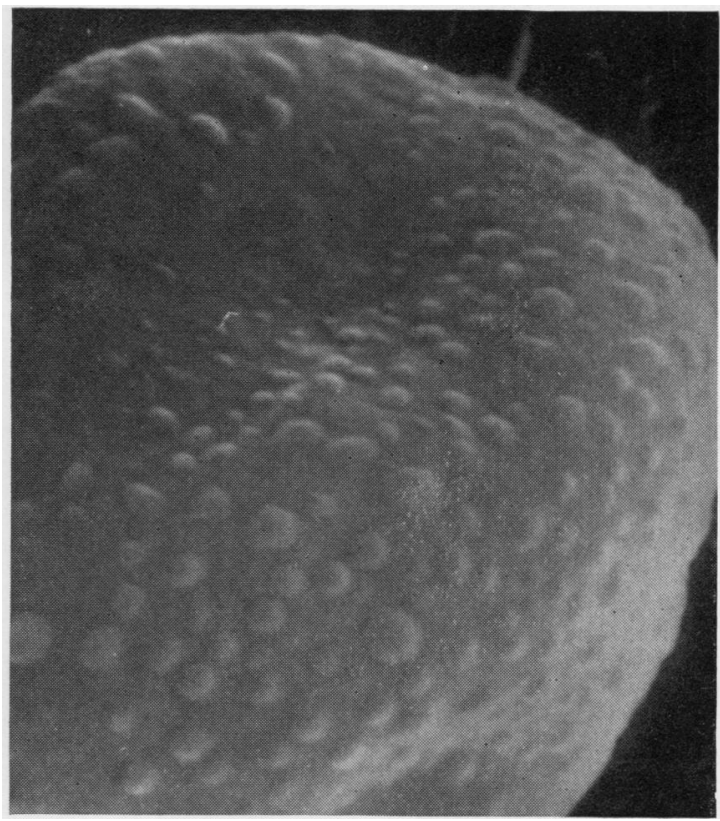

FIG. 3. Hereditary spherocytosis. Part of a spherocyte showing coarse surface granularity $\times 28,000$.

extending correspondingly. Other abnormal cells were seen in cases of sickle cell anaemia. These included crenated cells, spherical cells showing the vague outline of a nuclear shadow and probably normoblasts, and target cells with multiple small (700 $\AA$ diameter) regular defects in the cell unit membrane.

HEREDITARY SPHEROCYTOSIS As might have been expected, spherocytes were readily visualized. However, a surprising feature was the presence of coarse granules, ranging between 700 and $3,000 \AA$, on the surface of many spherocytes and also red blood 

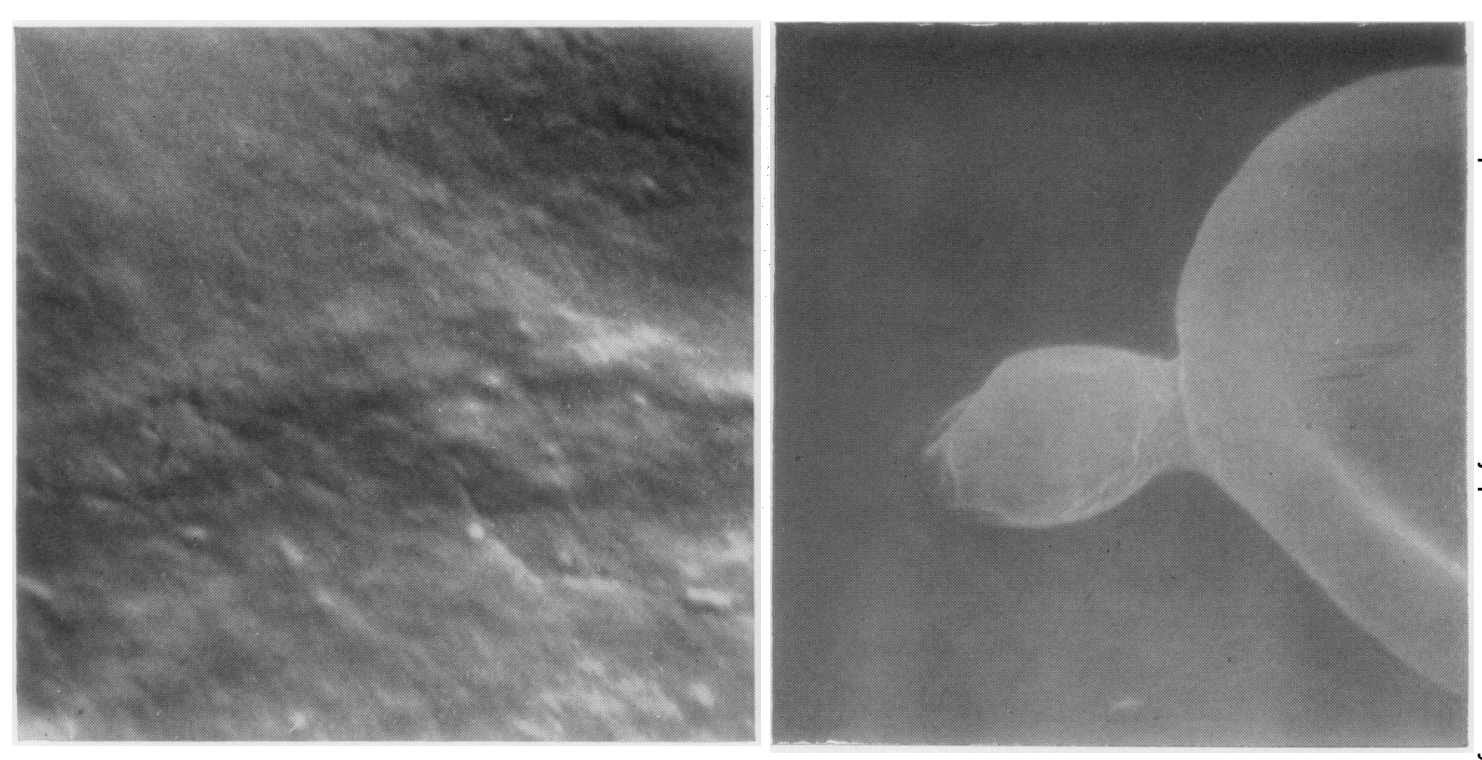

FIG. 4. Autoimmune haemolytic anaemia. Surface of a red cell showing fine granularity and small spherical bodies $\times 28,000$

FIG. 5. Autoimmune haemolytic anaemia. Possible nuclear extrusion by a red cell $\times 12,700$.

cells of otherwise normal appearance (Fig. 3). These granules were uniformly distributed over the surface of some cells and were accumulated around the borders of others. A few cells showed small, deep pits averaging $700 \AA$ in diameter on the surface of the cell. The pits almost always occurred singly.

AUTOIMMUNE HAEMOLYTIC ANAEMIA The majority of red cells showed $\imath$ fine granularity of their surface, the granules averaging $600 \AA$ in diameter. Granules were present both on red cells of normal appearance, on target-like cells, and on poikilocytes. In two instances of severe autoimmune haemolytic anaemia, in addition to the granularity, the surface of many red cells was studded with small spherical bodies, these averaging $480 \AA$ in diameter (Fig. 4).

Occasional cells showed small protrusions of the cell surface and in one instance a most remarkable appearance was seen. A roughly spherical body $2 \mu$ in diameter was attached to a red cell by a narrow stalk. This appeared to be an example of nuclear extrusion by the cell (Fig. 5).

No pitting of the red cell surface was seen in any of these samples.

PAROXYSMAL NOCTURNAL HAEMOGLOBINURIA Many, but not all, red cells exhibited an extraordinary plasticity, being deformed readily by surrounding cells (Fig. 6). Such cells tended to be macrocytic.

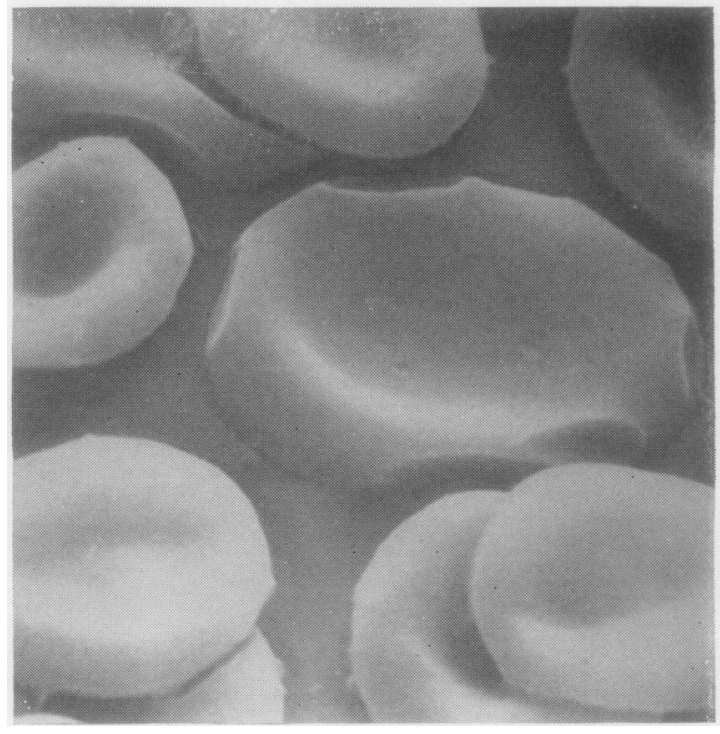

FIG. 6. Paroxysmal nocturnal haemoglobinuria. Red cell deformed by adjacent cells. $\times$ 5,900. 
The surface of the cells was generally smooth, although a few cells bore small, shallow depressions. Occasional cells showed small irregular areas of stripping of the cell membrane and in some instances such stripping was extensive.

In one case, a Ham's test was performed, samples being taken for examination at 10-minute intervals up to one hour. In these samples, there was a marked tendency for red cells to become crenated or to form poikilocytes of bizarre shapes, but no alterations in the surface membrane could be detected. Such cells eventually lysed, leaving 'ghosts'. The changes in red cell appearance were largely confined to the readily deformed red cells, red cells of normal appearance at the beginning of the test being relatively unaltered at its conclusion.

HAEMOLYTIC ANAEMIA SECONDARY TO INFECTION The red cell surface showed roughening but no granularity. In a few cells, irregular detachment of part of the nuclear membrane was noted. Moderate numbers of red cells showed pitting, the pits varying between $600 \AA$ and $1,200 \AA$ in diameter. Pitting was frequently multiple. In the case of the patient suffering from glandular fever, pitting disappeared during convalescence but the roughening of the red cell membrane persisted.

HAEMOLYTIC ANAEMIA SECONDARY TO DRUG SENSITIVITY The red cell surface was predominantly smooth, although a few cells showed a fine granularity. Moderate numbers of target cells and poikilocytes were seen. The most striking feature was the presence of large, deep pits in some red cells. The pits were circular, with a regular margin and ranged between $600 \AA$ and $4,500 \AA$ in diameter. The larger pits tended to occur singly, whereas the smaller pits were frequently multiple. In some cases, a pit near the border of the red cell was in close proximity to an apparent defect in the red cell surface (Fig. 7). No surface abnormality could be seen in the patient with Heinz bodies following a course of Dapsone.

HAEMOLYTIC ANAEMIA FROM MECHANICAL CAUSES The majority of red cells were of normal appearance, with smooth surfaces. Moderate numbers of finely granular cells, which were almost certainly reticulocytes, and of very bizarre poikilocytes were seen.

SIDEROBLASTIC ANAEMIA Red cells showed a marked variation in size and shape. Cells similar to those found in cases of iron-deficiency anaemia were numerous, and poikilocytes of a 'tear-drop' shape were prominent. The surface of these cells possessed a roughened appearance but was not granular. Occasional red cells bore single pits of an extra-

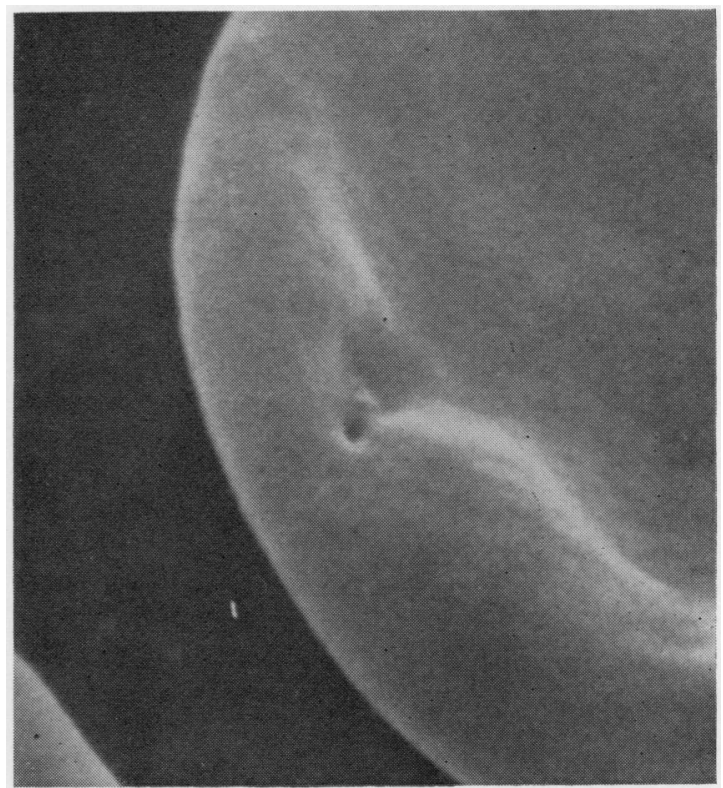

FIG. 7. Haemolytic anaemia due to phenacetin sensitivity. Small pit in red cell with adjacent defect in red cell surface. $\times 22,000$.

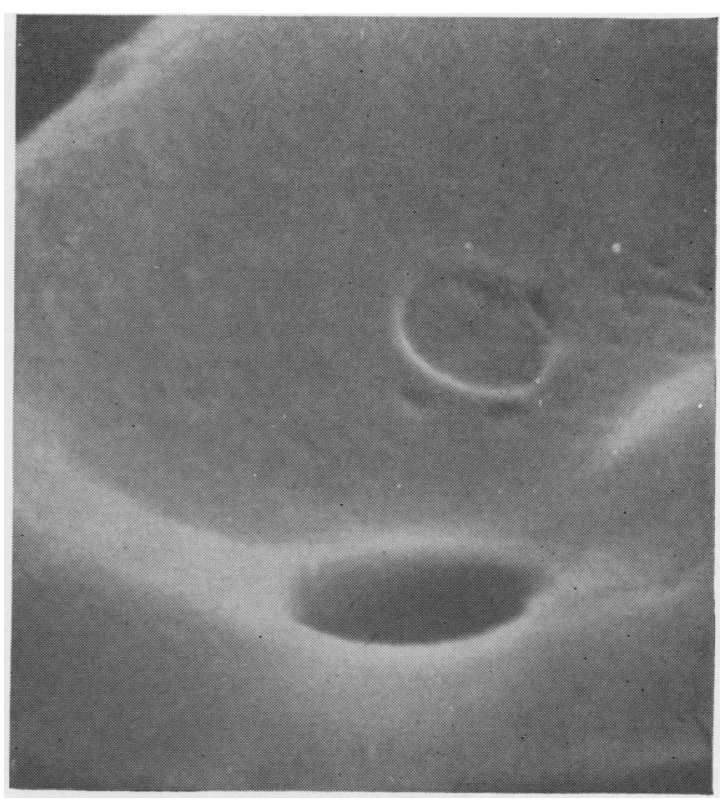

FIG. 8. Sideroblastic anaemia. Huge pit in red cell and crater-like defect in cell membrane. $\times 22,000$. 


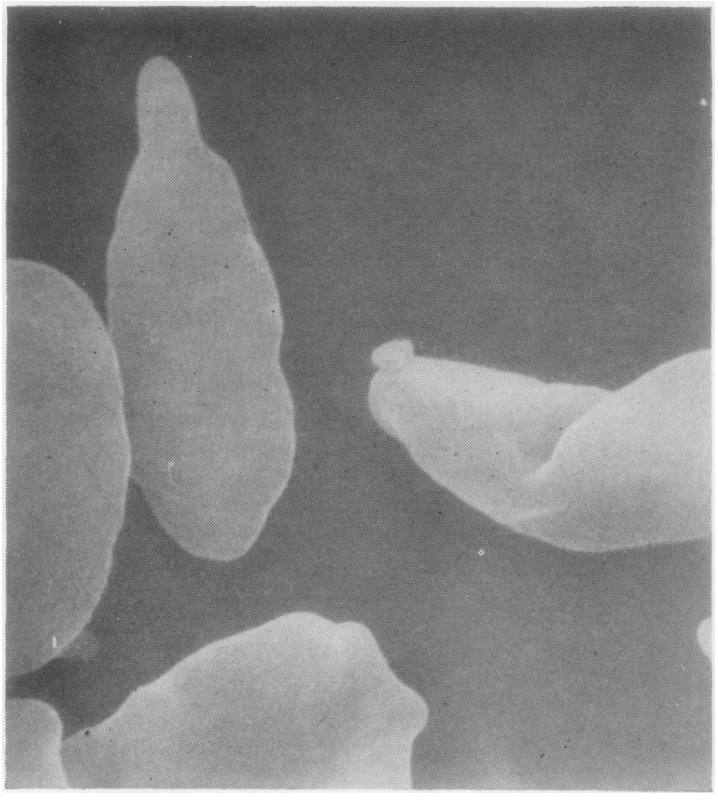

FIG. 9. Myelofibrosis. 'Tear-drop' poikilocytes. $\times$ 5,500 .

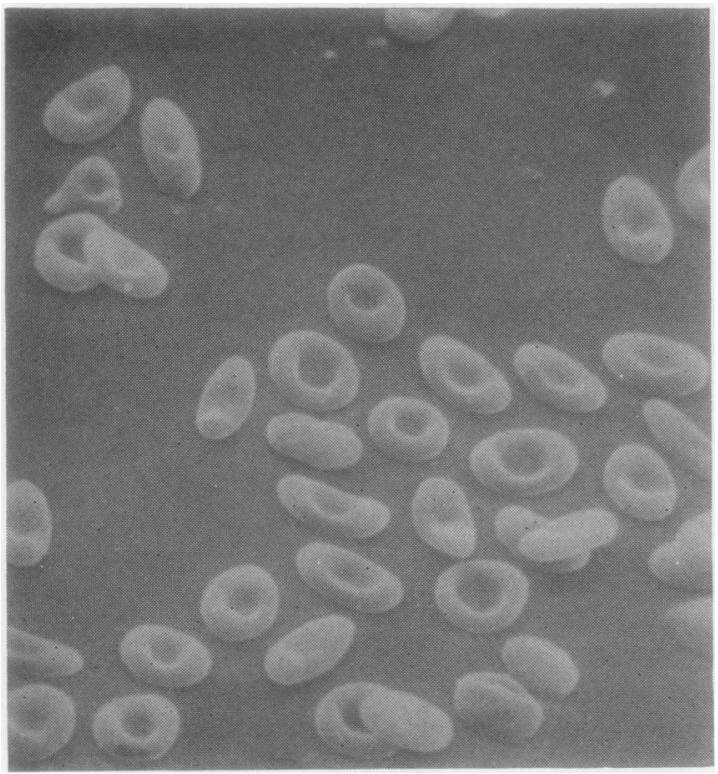

FIG. 11. Hereditary elliptocytosis. $\times 1,900$. ordinary size, between $5,000 \AA$ and $1 \mu$ in diameter (Fig. 8). These pits were circular, with a regular edge. By tilting the specimen, it could be seen that each pit extended deeply into the red cell. Some cells bearing pits also showed circular areas of apparent loss of the cell membrane.

MISCELLANEOUS Blood from cases of myelofibrosis contained many poikilocytes and crenated cells. \& 'Tear-drop' poikilocytes were prominent (Fig. 9).

Rouleaux formation was readily seen in cases of myelomatosis (Fig. 10). These samples also con- $\bar{\omega}$ tained poikilocytes of varied and interesting shapes.

An intriguing finding in blood from cases of $?$ uraemia was the presence of poikilocytes which

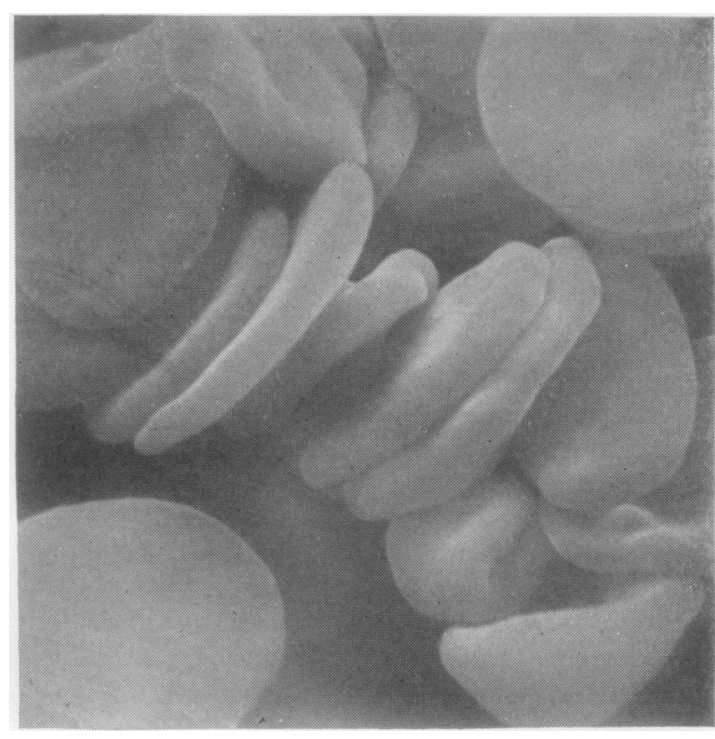

FIG. 10. Myelomatosis. Rouleaux formation. $\times 5,400$.

were a perfect facsimile of the normal red blood cell but which were only one quarter to two-thirds of its diameter.

A specimen from a case of asymptomatic elliptocytosis contained many well-preserved elliptocytes (Fig. 11).

ARTIFICIALLY INDUCED HAEMOLYSIS Red cells from a normal subject incubated with saponin showed $\overparen{D}$ defects in, and stripping of, the cell membrane $\stackrel{?}{+}$ within two seconds. In addition, many cells exhibited a coarse granulation within four seconds (Fig. 12). The granules were $1,000 \AA$ to $4,000 \AA$ in diameter, being very similar to the granules seen in hereditary spherocytosis. Haemolysis was usually complete within 10 seconds. 


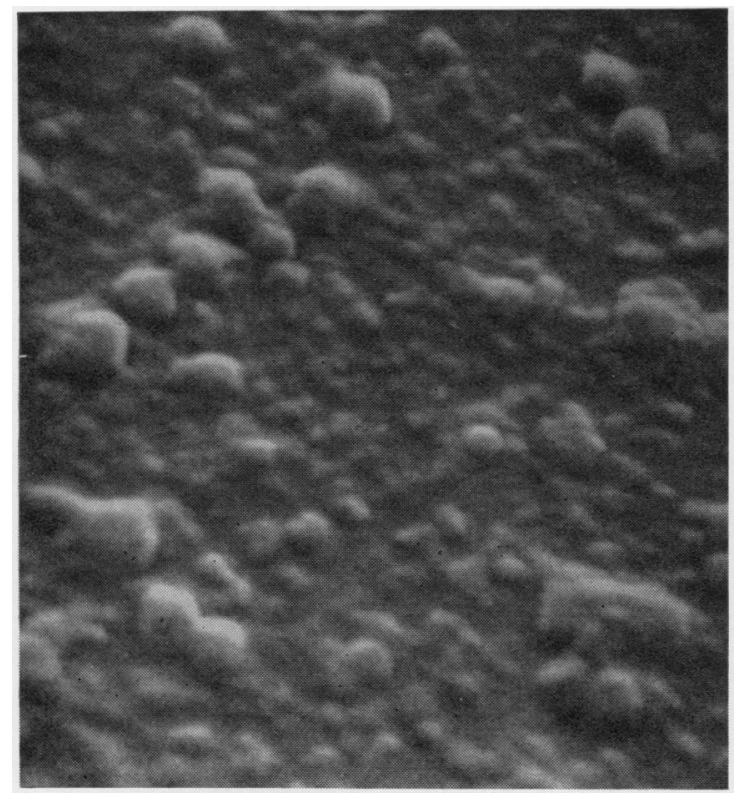

FIG. 12. Coarse granulation of the red cell surface produced after four seconds' incubation with saponin. $\times 25,000$.

Red cells incubated with streptolysin $\mathrm{O}$ showed a fine, regular granularity of the surface membrane within 10 seconds, but actual defects in the membrane were not observed at any time. Haemolysis was complete at five minutes, leaving a field strewn with irregular debris and occasional 'ghosts' of red blood cells.

\section{DISCUSSION}

The technical difficulties encountered in demonstrating the surface structure of the intact red cell membrane constitute a limiting factor in studying its appearance under. normal and pathological conditions.

Clearly optical microscopy is restricted by its lack of resolving power for examining fine detail. In contrast, electron microscopy utilizes indirect methods for examining the surface structure of red cells, since the intact cell is too thick to permit the selective passage of electrons. As a result, unless the isolated red cell membrane is examined in the electron microscope after shadowing with heavy metals, is negatively stained or the complete cell is thin sectioned and stained, attempts to study surface characteristics rely upon replica techniques, which are limited by the nature of the replicating material in demonstrating ultrastructure. The Stereoscan microscope can be used at light micro- scopic magnifications, since its depth of focus is some three hundred times greater than that of the conventional light microscope.

The present study has shown that the Stereoscan electron microscope provides a direct three-dimensional picture of the red cell membrane. The limiting factor with this instrument is its power of resolution (not less than $200 \AA$ ), but this is offset by its very large depth of focus. Consequently, examination of surface detail, alterations in contour, fissures, pores, or protuberances of the intact red cell membrane can be visualized with ease and without undue histological preparation. Thus the method is ideally suited for showing cell membrane morphology in a likeness whch cannot be provided by any other microscopical technique and at a resolution bridging the gap between optical and conventional transmission electron microscopes.

The most obvious question which must arise from the results of a new technique is, How many and which of the red cell abnormalities described are a result of artefacts? The only answer to this question is that one does not know. It must be remembered that red cell appearances in an air-dried film, fixed in methyl alcohol and stained with a Romanowsky stain, could be equally artefactual. Indeed, cells fixed in suspension are less subject to artefactual influences than conventional preparations involving film spreading and air-drying before fixation. With a new medium such as the Stereoscan electron microscope, assessment can only be made by experience and by correlation with information gained by other means. For example, the surface appearances described in this paper agree well with light microscopy findings concerning normal red cells, hyperchromic cells, 'tear-drop' poikilocytes, rouleaux formation, elliptocytes, target cells, and sickle cells.

Comparison of surface scanning electron microscopy with conventional transmission electron microscopy presents more problems. The granularity of the reticulocyte surface and the smooth surface of the majority of normal red cells is in accordance with the observations of Danon and Marikovsky (1961) on the effect of aging in vivo on the appearance of red cell membranes using the transmission electron microscope. The patchy loss of cell membrane, probably in aged red cells, which was so marked in blood taken after splenectomy may be compared with the irregular surface indentations described by Nathan and Gunn (1966) in platinum carbon shadow casts of red cell membranes from patients with thalassaemia who had undergone splenectomy.

Some cells from cases of paroxysmal nocturnal haemoglobinuria showed shallow depressions which could correspond to the pitting of red cell membranes 
in this condition described by Lewis, Danon, and Marikovsky (1965). The multiple holes produced in paroxysmal nocturnal haemoglobinuria cell membranes by complement (Rosse, Dourmashkin, and Humphrey, 1966) were not seen, almost certainly because such holes are only some $100 \AA$ in diameter, and the resolution of the Stereoscan instrument is $200 \AA$. For a similar reason, the regular array of defects in the red cell membrane produced by saponin (Dourmashkin, Dougherty, and Harris, 1962) were beyond the powers of resolution of the Stereoscan microscope. However, the failure to observe defects in the surface of red cells treated with streptolysin $O$ was disappointing, since such holes have been described as being about $500 \AA$ in diameter (Dourmashkin and Humphrey, unpublished observations). No explanation can be offered for this discrepancy.

The cell bearing a spherical body on a stalk in a case of autoimmune haemolytic anaemia was thought to be showing nuclear extrusion for the following reasons: (1) There was complete continuity via the stalk from the cell to the spherical body. (2) The body was of a size compatible with a pyknotic nucleus. (3) The surface of the body showed a roughened appearance identical to the surfaces of nuclei in preparations obtained by ultrasonic disintegration of blood cells. The appearance was unlike the small thin projections sometimes described in light microscopy of films from cases of autoimmune haemolytic anaemia, but the possibility that this was an example of a 'pincered' cell could not be completely excluded.

Several findings were most unexpected. The coarse granulation in cases of hereditary spherocytosis and the finer granulation in cases of autoimmune haemolytic anaemia could not readily be explained. It seemed unlikely that this granulation was artefact, since there was no background granulation and not all red cells in the same preparation were affected, but granularity occurred in some cells in every preparation from different subjects. Although the resolution of the Stereoscan microscope was insufficient to define antibodies such as macroglobulins, it was tempting to suppose that the small spherical bodies on the surface of red cells in some cases of autoimmune haemolytic anaemia were aggregations of antibody and, possibly complement.

The presence of small pores in the surface membranes of cells from cases of sickle cell anaemia and hereditary spherocytosis, of larger pits in cases of haemolytic anaemia secondary to infection or drugs, and of very large pits in cases of sideroblastic anaemia was even more mysterious. It was difficult to visualize how red cells with such defects could maintain their shape and survive in the circulation. The significance and nature of this pitting has yet to be determined. Since the pores were largely single, it is evident that a report of their presence in transmission electron microscope studies of sections was unlikely.

It will be appreciated that a great deal of work remains to be done on the surface appearance of red blood cells. In particular, further investigation of pitting and granularity of the red cell membrane is likely to lead to most interesting results.

Acknowledgement is made to the Cambridge Instrument Company for access to their instrument and to Miss Farrow for her technical assistance. Mr Tredinnick of the Department of Medical Photography, St. Bartholomew's Hospital, assisted with the illustrations. Professor D. L. Mollin kindly advised us during this study and made many helpful suggestions.

\section{REFERENCES}

Boyde, A., and Quilliam, T. A. (1966). Med. biol. Ill., 16, 116. -, and Stewart, A. D. G. (1963). Nature (Lond.), 198, 1102.

Clarke, J. A., and Salsbury, A. J. (1967). Ibid., In press.

Danon, D., and Marikovsky, Y. (1961). C. R. Soc. Biol. (Paris), $155,12$.

Dourmashkin, R. R., Dougherty, R. M., and Harris, R. J. C. (1962). Nature (Lond.), 194, 116.

Dourmashkin and Rosse (1966).

and Rosse, W. F. (1966). Amer. J. Med., 41, 699.

Lewis, S. M. (1967). Personal communication.

- Danon, D., and Marikovsky, Y. (1965). Brit. J. Haemat., 11, 689.

Nathan, D. G., and Gunn, R. B. (1966). Amer. J. Med., 47, 815.

Oatley, C. W., Nixon, W. C., and Pease, R. F. W. (1965). Advances in Electronics and Electron Physics, vol. 21, p. 181. Academic Press, New York.

Rosse, W. F., Dourmashkin, R., and Humphrey, J. H. (1966). J. exp. Med., 123, 969.

Thornton, P. R. (1965). Science, Nov. 1965, 65. 